\title{
Relationship between Knowledge and Using Personal Protective Equipment in Tuberculosis Ward and Polyclinic of Hospital X
}

Hubungan antara Pengetahuan dan Penggunaan Alat Pelindung Diri di Bangsal dan Poliklinik Tuberkulosis Rumah Sakit $X$

\author{
Ekorini Listiowati ${ }^{1}$, Fitria Eka Rianti ${ }^{2}$ \\ 1 Universitas Muhammadiyah Yogyakarta \\ ${ }^{2}$ Program Studi Pendidikan Dokter, Fakultas Kedokteran dan IImu Kesehatan, Universitas Muhammadiyah Yogyakarta
}

DATA OF ARTICLE:

Received: 22 April 2019

Reviewed: 19 Jun 2019

Revised: 13 April 2020

Accepted: 12 Feb 2021

\section{*CORRESPONDENCE:}

ekorini_santosa@umy.ac.id

DOI:

10.18196/mmjkk.v21i1.6157

TYPE OF ARTICLE:

Research
Abstract: Tuberculosis (TB) prevalence in Indonesia occupies the $2^{\text {nd }}$ position globally; therefore, it is necessary to prevent TB transmission, including the use of Personal Protective Equipment (PPE) in high-risk individuals. This study aims to determine the relationship between nurses' knowledge and behavior in using PPE to prevent TB transmission in hospitals. This study used a cross-sectional design, with the research subjects of all nurses in the isolation room and the TB polyclinic in a private hospital $(\mathrm{X})$ in Yogyakarta. The study was attended by 38 nurses, with a total sampling technique. Data were obtained using a questionnaire. The data analysis employed descriptive statistical tests and chi-square. This study's results indicated that most nurses had good knowledge (31 people; $81.6 \%$ ) and good behavior (32 people; $84.2 \%$ ). Chi-square analysis revealed a significant relationship between knowledge and nurses' behavior in using PPE $(p=0.000)$. It was concluded that there was a significant relationship between knowledge and nurses' behavior in using $\mathrm{PPE}$ in the TB ward and polyclinic at Hospital X.

Keywords: personal protective equipment; behavior; knowledge; tuberculosis

Abstrak: Prevalensi Tuberkulosis (TB) di Indonesia menempati posisi ke-2 di dunia, oleh karena itu diperlukan upaya pencegahan penularan TB diantaranya dengan penggunaan Alat Pelindung Diri (APD) pada individu berisiko tinggi. Penelitian ini bertujuan untuk mengetahui hubungan pengetahuan dan perilaku perawat dalam penggunaan APD untuk pencegahan penularan TB di Rumah Sakit (RS). Penelitian ini menggunakan desain cross sectional, dengan subjek penelitian seluruh perawat di ruang isolasi dan poliklinik TB di RS $\chi$ di Yogyakarta. Penelitian dikuti oleh 38 perawat, dengan teknik total sampling. Data diperoleh dengan menggunakan kuesioner. Analisis data menggunakan uji statistik deskriptif dan chi square. Hasil penelitian ini menunjukkan sebagian besar perawat memiliki pengetahuan baik (31 orang; 81,6\%) dan berperilaku baik (32 orang; 84,2\%). Analisis chi square menunjukkan ada signifikansi hubungan antara pengetahuan dengan perilaku perawat dalam penggunaan APD ( $p=0,000)$. Disimpulkan bahwa terdapat hubungan yang signifikan antara pengetahuan dan perilaku perawat dalam penggunaan APD di bangsal dan poliklinik TB di RS X.

Kata kunci: alat pelindung diri; pengetahuan; perilaku; tuberkulosis 


\section{INTRODUCTION}

Tuberculosis (TB) is a disease that is transmitted very quickly. TB incidence globally is increasing, and it is the biggest health problem, especially in developing countries. Therefore, the Word Health Organization (WHO) states that TB is a global health emergency. ${ }^{1}$ One of the targets for achieving the Millennium Development Goals (MDGs) number 6 in 2015 is handling TB and Human Immunodeficiency Virus (HIV). Regarding TB infection control and prevention, WHO recommends four pillars, namely managerial, administrative control, environmental control, and self-protection control. ${ }^{2}$

According to the WHO report (2013), ${ }^{1}$ it was estimated that there were 8.6 million TB cases (2012), of which 1.1 million sufferers (13\%) were HIV-positive TB patients. Based on these reports, $75 \%$ of the population was in the African region. An estimated 450,000 people with Multi Drugs Resistance (TB MDR) tuberculosis in Africa and 170,000 of them died. ${ }^{1}$ Most of the deaths in TB patients occurred in men, with an estimated number of 250 people and an estimated 160 people in women. ${ }^{1}$ Many occurred in children; it was estimated that there were 530,000 or $6 \%$ of new cases per year, while deaths in children caused by TB were 74,000 or an estimated $8 \%$ in 2012.

According to data in the Yogyakarta Health Office for $2011-2014,3$ there was a slight decrease in TB prevalence in 2013 and 2014. It was recorded that in 2013, there were 243 cases of TB BTA (+) and 211 cases in 2014 , with the proportion of 60 new cases, $18 \%$ for men and $39.82 \%$ for women. The data showed that out of 18 Community Health Centers, 8 Hospitals, and 2 Lung Medicine Center (BP-4), there was a slight decline in 2014. The cure rate for TB sufferers in the Yogyakarta region in 2008 - 2014 had not reached the national target of $85 \%$ yet, even tending to decline from 2011-2014..$^{3}$ The cure rate in 2011 only reached $79 \%$, it decreased to $72 \%$ in 2012 , in 2013 , it reached $75.9 \%$, and it decreased again in 2014 , namely by $75.72 \%{ }^{3}$

Besides, the transmission of the infection occurs through body fluids and blood. A nurse is a profession that is at risk of contracting TB disease. Nurses non-compliance in using PPE can increase the risk of disease transmission. ${ }^{4}$ The research conducted at hospitals in Banten Province uncovered that non-compliance behaviors that often occurred were the use of masks and hands coons or both in carrying out nursing actions. $^{4}$

Previous research at Hospital X exposed that the TB incidence rate was 118 patients from January 2016 until March 2017. If measured by Tuberculosis Directly Observed Treatment Short-course (TB DOTS), the achievement rate of TB patients was $0.8 \%$, which reached default, the failure rate was $0.3 \%$, the cure rate was $11.2 \%$, the conversion rate was $32.7 \%$, and the complete treatment rate was $43.5 \% .^{6}$ The high number of TB patients and the low cure rate at Hospital $X$ is essential for research related to PPE use, especially by nurses who work in the TB clinic and ward.

\section{MATERIALS AND METHODS}

This research is quantitative with an observational analytic design using a cross-sectional design. This study aims to analyze the relationship between nurses' knowledge level and behavior in using PPE, especially in the TB Ward and Polyclinic. The research was conducted at a private hospital in Yogyakarta (X). In this study, the population and sample were all nurses who worked in the TB isolation room and TB polyclinic. There were 38 respondents involved, with a total sampling technique.

The MCQ questionnaire sheet was utilized to see nurses' knowledge, while the Likert scale questionnaire sheet was employed to see nurses' behavior. Data analysis in this study was carried out using the SPSS 1.5 program to analyze univariate (descriptive) and bivariate (chi-square).

\section{RESULTS}

Nurse Characteristics. The characteristics of the respondents in this study are presented in Table 1. Table 1 shows that most respondents were female (65.8\%), aged $26-35$ years (65.8\%), had a tenure of $1-5$ years (81.6\%), and have a bachelor's degree (55.3\%).

Knowledge and Behavior. Based on the results, nurses' knowledge level at Hospital X was generally good (31 nurses: $81.6 \%$ ). Specifically (Table 2), based on gender, it appeared that $84.6 \%$ of male nurses and $80 \%$ of female nurses had good knowledge. Based on age, the group 17-25 years and 26-35 years were knowledgeable, as much as $83.3 \%$ and $80.0 \%$, respectively. Based on the tenure, $83.9 \%$ of nurses with a work period of 1-5 years had good knowledge. Based on education, it appeared that $90 \%$ of nurses with a bachelor's education had good knowledge.

Relationship between Knowledge and Behavior of Nurses in Using PPE. The correlation analysis results using chi-square are displayed in Table 3. Table 3 reveals that respondents with good knowledge were $81.6 \%$, along with respondents who had good behavior (84.2\%). Meanwhile, respondents with sufficient 
Vol 21 No 1

January 2021

knowledge (18.4\%) were also in line with respondents who had sufficient behavior (15.8\%). No respondents were less knowledgeable or behaved less. The chi-square analysis results showed a significant correlation ( $p$ $=0.006)$, with a strong correlation $(r=0.7553)$.

Table 1. Characteristics of Nurses in TB Ward and Polyclinic of Hospital X Year 2017

\begin{tabular}{|c|c|c|c|}
\hline \multirow{2}{*}{ No } & \multirow{2}{*}{ Characteristics of Nurses } & \multicolumn{2}{|c|}{ Frequency } \\
\hline & & $\mathrm{F}$ & $\%$ \\
\hline \multirow[t]{3}{*}{1} & Sex & & \\
\hline & Male & 13 & 34.2 \\
\hline & Female & 25 & 65.8 \\
\hline \multirow[t]{4}{*}{2} & Age & & \\
\hline & $17-25$ year & 12 & 31.6 \\
\hline & $26-35$ year & 25 & 65.8 \\
\hline & $36-45$ year & 1 & 2.6 \\
\hline \multirow[t]{5}{*}{3} & Tenure & & \\
\hline & $<1$ year & 4 & 10.5 \\
\hline & $1-5$ year & 31 & 81.6 \\
\hline & $6-10$ year & 2 & 5.3 \\
\hline & $>10$ year & 1 & 2.6 \\
\hline \multirow[t]{3}{*}{4} & Education & & \\
\hline & Diploma & 18 & 44.7 \\
\hline & Bachelor & 20 & 55.3 \\
\hline
\end{tabular}

Source: Primary Data

Table 2. Characteristics of Nurses' Level of Knowledge and Behavior in the use of PPE in TB Ward and Polyclinic of Hospital X

\begin{tabular}{|c|c|c|c|c|c|c|c|c|c|c|c|c|c|}
\hline \multirow{3}{*}{ No } & \multirow{3}{*}{ Characteristics } & \multicolumn{6}{|c|}{ Knowledge } & \multicolumn{6}{|c|}{ Behavior } \\
\hline & & \multicolumn{2}{|c|}{ Good } & \multicolumn{2}{|c|}{ Moderate } & \multicolumn{2}{|c|}{$\mathrm{Bad}$} & \multicolumn{2}{|c|}{ Good } & \multicolumn{2}{|c|}{ Moderate } & \multicolumn{2}{|c|}{$\mathrm{Bad}$} \\
\hline & & $\mathrm{F}$ & $\%$ & $\mathrm{~F}$ & $\%$ & $\mathrm{~F}$ & $\%$ & $\mathrm{~F}$ & $\%$ & $\mathrm{~F}$ & $\%$ & $\mathrm{~F}$ & $\%$ \\
\hline \multirow[t]{3}{*}{1} & Sex & & & & & & & & & & & & \\
\hline & Male & 11 & 84.6 & 2 & 15.4 & 0 & 00 & 12 & 92.3 & 1 & 7.7 & 0 & 00 \\
\hline & Female & 20 & 80 & 5 & 20 & 0 & 00 & 20 & 80 & 5 & 20 & 0 & 00 \\
\hline \multirow[t]{4}{*}{2} & Age & & & & & & & & & & & & \\
\hline & $17-25$ year & 10 & 83.3 & 2 & 16.7 & 0 & 00 & 12 & 100 & 0 & 00 & 0 & 00 \\
\hline & $26-35$ year & 20 & 80 & 5 & 20 & 0 & 00 & 19 & 76 & 6 & 24 & 0 & 00 \\
\hline & $36-45$ year & 1 & 100 & 0 & 00 & 0 & 00 & 1 & 100 & 0 & 00 & 0 & 00 \\
\hline \multirow[t]{5}{*}{3} & Tenure & & & & & & & & & & & & \\
\hline & $<1$ year & 2 & 50 & 2 & 50 & 0 & 00 & 3 & 75 & 1 & 25 & 0 & 00 \\
\hline & $1-5$ year & 26 & 83.9 & 5 & 16.1 & 0 & 00 & 26 & 83.9 & 5 & 16.1 & 0 & 00 \\
\hline & $6-10$ year & 2 & 100 & 0 & 00 & 0 & 00 & 2 & 100 & 0 & 00 & 0 & 00 \\
\hline & $>10$ year & 1 & 100 & 0 & 00 & 0 & 00 & 1 & 100 & 0 & 00 & 0 & 00 \\
\hline \multirow[t]{3}{*}{4} & Education & & & & & & & & & & & & \\
\hline & Diploma & 13 & 72.2 & 5 & 27.8 & 0 & 00 & 15 & 83.3 & 3 & 16.7 & 0 & 00 \\
\hline & Bachelor & 18 & 90 & 2 & 10 & 0 & 00 & 17 & 85 & 3 & 15 & 0 & 00 \\
\hline
\end{tabular}

Source: Primary Data 
Table 3. The Relationship between Knowledge and Nurse Behavior in Using PPE in TB Ward and Polyclinic of Hospital X

\begin{tabular}{ccccccc}
\hline \multirow{2}{*}{ Category } & \multicolumn{2}{c}{ Knowledge } & \multicolumn{3}{c}{ Behavior } & \multicolumn{2}{c}{ Chi-square } \\
\cline { 2 - 7 } & $\mathrm{F}$ & $\%$ & $\mathrm{~F}$ & $\mathrm{p}$ & $\begin{array}{c}\text { Correlation } \\
\text { Coefficient }\end{array}$ \\
\hline Good & 31 & 81.6 & 32 & 84.2 & & \\
Moderate & 7 & 18.4 & 6 & 15.8 & 0.006 & 0.7553 \\
Bad & 0 & 00 & 0 & 00 & & \\
\hline
\end{tabular}

Source: Primary Data

\section{DISCUSSION}

Knowledge about PPE by Gender. This study's results indicated that both male and female nurses had good knowledge about PPE. It is in line with Robbins (2014), ? that men and women both have the opportunity to have a good level of knowledge. Likewise, with behavior, there is no significant difference between men and women in carrying out work. In psychological theory, women are more willing to fulfill authority than men, but men are more aggressive and have a high chance of success, although this difference is very small. ${ }^{7}$ Nurses who have a high level of knowledge will tend to carry out their duties according to their knowledge and understanding of the actions impact. ${ }^{8}$

Knowledge of Nurse PPE by Age. The results showed that the highest value of knowledge about PPE was in the age group of 36-45 years. It is in line with research conducted by Anawati et al. (2012), ${ }^{9}$ which verified that respondents aged 30-40 years had a good knowledge level of 55.2\%. Mature age would affect nurses' knowledge about the use of PPE so that nurses could improve the quality of providing services to patients and increase knowledge. Besides, the older a person is, the more his mental development strength increases. ${ }^{10}$

Knowledge of Nurses about PPE Based on Tenure. This study was dominated by nurses with a work period of 1-5 years. If tenure and knowledge level were related, it could be seen from Table 2 that the higher the tenure, the higher the percentage of well-informed nurses. The tenure is an individual experience to bring out the ability to work. Much experience will increase skills and abilities at work. The work experience of a nurse is very strongly related to his knowledge. Nurses who apply their experience well and make learning resources will have good and professional skills and knowledge at work so that nurses can provide quality service to patients. ${ }^{11}$ According to Christensen and Kenney (2009), ${ }^{12}$ the more experience a nurse has, the more knowledge about himself, patient rights, patient needs, ability to explain to patients, and can handle actions under the applicable procedures.

Knowledge of Nurses about PPE Based on Education. The nurses' compliance level in using PPE was influenced by the education level. In this study, most (90\%) nurses with a bachelor's education had good knowledge, while $72.2 \%$ of nurses with a Diploma-3 education also had good knowledge. This study's results are in accordance with the opinion of Rini (2016), ${ }^{11}$ that nurses who had a higher level of education had a much better level of knowledge because, in the educational process, they would go through a series of learning activities, gaining broad understanding, knowledge, and insight. Education is needed by someone to get information about health so that there is an increase in life quality. ${ }^{13}$ According to Notoatmodjo (2014), ${ }^{14}$ if someone has high knowledge, the easier he is to receive information.

PPE Use Behavior Based on Gender. The results disclosed that there was no significant difference between the behavior of men and women. For male respondents, 12 people ( $92.3 \%$ ) had good behavior, and one person (7.7\%) had sufficient behavior. For female respondents, $20(80 \%)$ had good behavior, and $5(20 \%)$ had sufficient behavior. This study's results align with research carried out by Apriluana (2016), ${ }^{15}$ which revealed that there was no significant relationship between gender and the availability of PPE with the behavior of health personnel using PPE in Banjarbaru Hospital. It signified that the behavior of using PPE on male nurses and women was the same, and it was not related to the availability of PPE. Nurse professionalism is vital, regardless of gender differences. However, several studies have shown that the nursing profession is more in demand by women than men because women are considered to have maternal instincts. The number of nurses in several hospitals is also more women. However, currently, for reasons of gender equality, the need for specific skills and dexterity such as in the Operating Room (OK) and Emergency Unit (UCD), or because of the development of science, the presence of male nurses is starting to be taken into account. ${ }^{16}$

PPE Use Behavior Based on Age. This study involved 38 nurses who were dominated by nurses aged 26-35 years. Analysis of nurses behavior based on age showed that nurses aged 17-25 years had the highest 
percentage of the behavior value of using PPE, and one nurse aged 36-45 years had good behavior. According to Nursalam (2011), ${ }^{17}$ ages play an essential role in determining a person to be more Table. The older a person is, the better the level of thinking ability and strength at work. Someone more mature will tend to be more trusted because of the maturity of his soul.

PPE Use Behavior based on the working period. In this study, the highest percentage of PPE use behavior values was among nurses with a work period of 6-10 years and $>10$ years. Meanwhile, this research was dominated by nurses who had a work period of 1-5 years. Trisno (2010), ${ }^{18}$ concluded that 18 on 422 workers in a company showed no relationship between years of service and use of PPE and worked accidents $\left(r^{2}=0.002 ; p=0.813\right)$. According to Wibowo et al. (2013), ${ }^{16}$ people who have a more extended working period sometimes decrease productivity due to boredom. The length of work for a person is synonymous with experience; the longer the work period, the more experience increases so that the knowledge increases, ${ }^{16}$ but not necessarily followed by better behavior.

PPE Use Behavior Based on Education. The study demonstrated that the highest percentage of scores was for nurses with a bachelor's education level. It is consistent with the research conducted by Wibowo AS et al. (2013), ${ }^{16}$ that a person with higher education would have better knowledge and professionalism. It also applied to the knowledge and use of PPE. In accordance with Wawan and Dewi's (2010) statement, ${ }^{19}$ education could influence a person, including the behavior of life patterns. The higher a person's education, the easier he will be to receive information so that his/her insight will be broader.

Relationship between Knowledge and Behavior in the Use of PPE. The analysis results using ChiSquare showed a significant relationship between the level of knowledge and the behavior of nurses in using PPE while on duty in the ward and tuberculosis clinic in Hospital X ( $p=0.006)$. This study corroborates the research conducted by Zahara et al. (2017), ${ }^{20}$ that there was a relationship between knowledge $(p=0.001)$ and behavior $(p=0.006)$ of nurses with compliance with the use of PPE. However, these results are not consistent with Rini's (2016) research, ${ }^{11}$ that there was no relationship between the level of knowledge and the behavior of using PPE ( $p=0.465 ; a=0.05)$. It might be due to other factors influencing standard precautionary behavior, such as supporting facilities that did not comply with standards, the composition of the disinfection fluid used was uncertain, and there was no detailed and specific Standard Operational Procedure (SOP).

\section{CONCLUSION}

In general, nurses in the TB ward and polyclinic of Hospital X had a good level of knowledge and behavior. No nurse had a less behavioral level in terms of length of work and gender. Thus, there was a relationship between the knowledge and behavior of nurses and the use of PPE.

\section{REFERENCES}

1. WHO. Global Tuberculosis Report 2013. World Health Organization. 2013. https://apps.who.int/iris/handle/10665/91355

2. Kemenkes, RI. Pedoman Pencegahan dan Pengendalian Infeksi Tuberkulosis di Fasilitas Pelayanan Kesehatan. 2012. https://docplayer.info/33206916-Pedoman-pencegahan-dan-pengendalian-infeksituberkulosis-di-fasilitas-pelayanan-k-esehatan.html

3. DinKes Provinsi DIY. Profil Kesehatan Provinsi D I Yogyakarta Tahun 2011. 2011.

4. Riyanto DA. Faktor-faktor yang Mempengaruhi Kepatuhan Perawat dalam Penggunaan Alat Pelindung Diri di Rumah Sakit Sari Asih Serang Provinsi Banten. 9 (2016). http://ejournal.stikesborromeus.ac.id/file/58.pdf

5. Jamsostek. Laporan Tahunan 2011. https://www.bpjsketenagakerjaan.go.id//assets/uploads/laporan_tahunan/02022015_140606_ar\%20ja msostek\%202011\%20lores.pdf

6. Prameswari A. The Evaluation of Directly Observed Treatment Short-Course (DOTS) Implementation for TB in Hospital X. JMMR (Jurnal Medicoeticolegal dan Manajemen Rumah Sakit), 7 (2): p. 93-101, August 2018. https://doi.org/10.18196/jmmr.7261

7. Robbins SP, Judge TA. Perilaku Organisasi. in Perilaku Organisasi vol. Edisi 16. Salemba Empat. 2014.

8. Notoadmodjo S. Promosi kesehatan. Rineka Cipta. Jakarta. 2010.

9. Anawati KR, Ungaran MPSNW, Ungaran DPSNW. Hubungan Pengetahuan dan Sikap dengan Kepatuhan Perawat dalam Penggunaan Alat Pelindung Diri di Rumah Sakit Umum Daerah Ambarawa. 
https://docplayer.info/72343254-Hubungan-pengetahuan-dan-sikap-dengan-kepatuhan-perawat-dalampenggunaan-alat-pelindung-diri-di-rumah-sakit-umum-daerah-ambarawa.html (2012).

10. Soekanto S. Sosiologi Suatu Pengantar. Rajawali Pers. 2012.

11. Rini MK. Gambaran Pengetahuan Perawat tentang Penggunaan Alat Pelindung Diri di Bangsal Medikal Bedah Rawat Inap Rumah Sakit PKU Muhammadiyah Gamping Sleman. Universitas Muhammadiyah Yogyakarta (2016). http://repository.umy.ac.id/handle/123456789/2926

12. Christensen P, Kenney JW. Proses Keperawatan Aplikasi Model Konseptual. EGC. 2009.

13. Wawan A \& Dewi M Pengetahuan, Sikap, dan Perilaku Manusia cetakan ke II. Nuha Medika. 2011.

14. Notoatmojo S. Promosi Kesehatan dan Perilaku Kesehatan. Rineka Cipta. 2014.

15. Apriluana G, Khairiyati L, Setyaningrum R. Hubungan Antara Usia, Jenis Kelamin, Lama Kerja, Pengetahuan, Sikap Dan Ketersediaan Alat Pelindung Diri (Apd) Dengan Perilaku Penggunaan Apd Pada Tenaga Kesehatan. Jurnal Publikasi Kesehatan Masyarakat Indonesia (JPKMI), 3(3), p. 82-87. 6. 2016.

16. Wibowo AS, Suryani M. Hubungan Karakteristik Perawat dengan Penggunaan Sarung Tangan pada Tindakan Invasif di Ruang Rawat Inap RSUD dr. Soewondo Kendal. 9. 2013. http://ejournal.stikestelogorejo.ac.id/index.php/ilmukeperawatan/article/view/157

17. Nursalam. Manajemen Keperawatan: Aplikasi dalam Praktik Keperawatan Profesional Edisi 3. (Salemba Medika, 2011).

18. Trisno. Penderita HIV-AIDS di Jateng 2.922 orang. in Suara Medika.com. 2010.

19. Wawan A, Dewi M. Teori dan Pengukuran Pengetahuan, Sikap, dan Perilaku Manusia. Nuha Medika. 2010.

20. Zahara RA, Effendi SU, Khairani N. Kepatuhan Menggunakan Alat Pelindung Diri (APD) Ditinjau dari Pengetahuan dan Perilaku pada Petugas Instalasi Pemeliharaan Sarana Dan Prasarana Rumah Sakit (IPSRS). J. Sci.n.a 2, p. 153-158. 2017. 